\title{
INTRODUCTION
}

\section{The Ethnographic Praxis of the Theory of Practice}

\author{
T. M. S. Evens and Don Handelman
}

The ethnographic extended-case method, also known as situational analysis, was a diagnostic of the Manchester School of Social Anthropology-and today it remains an ethnographic practice of remarkable relevance and promise. Originated by Max Gluckman, the method was intended to use case material in a highly original way. Instead of citing examples from ethnography in apt illustration of general ethnographic and analytical statements, as was common in the discipline, Gluckman proposed to turn this relationship between case and statement on its head: the idea was to arrive at the general through the dynamic particularity of the case. Rather than a prop, the case became in effect the first step of ethnographic analysis. Underlying this methodological reversal, though, was a theoretical pursuit pertaining to an enveloping, indeed a suffocating, problem endemic to structural functionalism and implicating a social ontology radically different from this dominant paradigm.

As a young man in South Africa, Gluckman had studied law in university; he also was known throughout his career to have a certain affinity with psychoanalytical thought. Given the critical centrality of the notion of case in these two fields of study, using cases in a way essential to advancing his own discipline-ethnographic research-might well have had an intuitive appeal to Gluckman. At any rate, he grasped and shaped the case method in relation to the problem of "the on-going process of social life" (1965: 177), a problem with which he and his peers were inescapably confronted.

Gluckman's basic anthropological training was in structural functionalism, via, pre-eminently, Radcliffe-Brown's rendering of Durkheim. Plainly, the vital thesis of this paradigm - that the explanation of a social phenomenon is a matter of determining its function in reproducing the social structure in its current form-tended to picture society in terms of stability and equilibrium. This thesis recognized social process, yet only insofar as process was reducible to, and so in the service of, social stasis. In turn, the thesis created an undesirable, though virtual, constituent problem of the paradigm - to wit, the problem of 
how to explain social process that not only failed to contribute to the preservation of the status quo but also contravened or disrupted it. 'Disruptive' process of this kind loomed all too visible as intensive ethnographic fieldwork became the rule in social anthropology.

Gluckman's peers addressed this problem in a variety of ways, including the notable examples of Nadel's (1957) and Firth's (1961) psychologistic introduction of individual choice as the means by which to account for this kind of intrinsically generative process. In their psychologism they were inspired by their mentor, Bronislaw Malinowski. Gluckman, though influenced by Malinowski's ethnographic empiricism (a focused attention on how people actually behaved), was not taken with his psychologism. Moreover, Gluckman was disinclined by his strong Durkheimian persuasion to reduce social process to individual choice. Instead, influenced by an ardent commitment to empirical investigation and a deep and abiding interest in social conflict, Gluckman hit on the idea of scrutinizing particular situations of conflict as complexes of connected incidents that were occurring in the field, in order to isolate and identify the actual mechanisms underlying the development of the conflict.

The idea was to take the actors and their roles in any particular incident and trace these self-same actors through other incidents, in this way linking the varied incidents to one another and identifying the actual mechanisms (as logically distinct from the normative principles) operating in the relevant social order. So instead of trying to resolve the problem of process through theory alone (as, e.g., in Nadel's and Firth's theoretical recourse to the ontological dualism of the individual and society), Gluckman latched onto the idea of empirically isolating and identifying the social mechanisms that constituted process as such. He did this by analyzing conflicts ("trouble cases," as he named them) in their concrete emergence or as extending over a range of situations.

The development of the extended-case method stemmed most immediately from this constitutional incapacity of structural functionalism to address the issue of social process, as just described. As a 'method', it was above all intended as a means to overcome this incapacity and thereby to save the structural-functionalist paradigm. The method was designed to force the paradigm to confront the empirical realities of social process and their contribution to the state of the social order, thus rescuing structural functionalism from what seemed a fatal flaw. Yet this turn to social process as process probably did more to undermine structural functionalism than to save it, ultimately proving the flaw in question to be fatal and thereby promoting a shift in paradigms. It is in this connection that the extended-case method or situational analysis most emphatically warrants revisiting today, in the context of current anthropology.

The method enjoys a very practical ethnographic advantage in that first and foremost it requires attention to ethnographic detail. This gives the fieldworker a clear and specific empirical focus, without pre-judging this focus theoretically or ideologically. So, too, in light of the resulting case narrative, this attention to detail helps greatly to organize the writing up of the mire of data that field research typically produces. Nonetheless, the current principal relevance of situational analysis is not practical but instead emphatically theoretical, taking 
off from the implicit direction that this so-called method gave to the shift away from the structural-functionalist paradigm.

To perceive this, it is necessary to stress that the development of the method had a condition even deeper than, though closely related to, the ever-pressing need to remedy the constitutional weakness of structural functionalism's inability to recognize social process. This condition was so theoretically atmospheric that its contribution in the forging of the extended-case method was obscured, perhaps even to Gluckman. We have in mind Gluckman's broad and distinctive focus on political conflict and, more abstractly, on contradiction as key to social order and process. ${ }^{1}$ Whether in his pioneering work on the anthropology of law or his more general analyses of tribal social orders, he was inclined to see conflict as the counter-intuitive optic through which to discern the essential character of any social order and, correlatively, to grasp this character in terms of basic principles that are at variance with one another. In this connection Gluckman had been powerfully influenced by Evans-Pritchard's stupendous analysis of how among the Nuer conflicting loyalties and crosscutting ties brought about order without government (or as Evans-Pritchard otherwise put it, “ordered anarchy”). But the force of Gluckman's views on conflict and social order is distinctly dialectical and as such, notwithstanding his admiration of Evans-Pritchard and his Durkheimian bent, most likely finds its essential philosophical spirit in the Marxian tradition. Though he made little direct reference to it in his work, his familiarity with Marxian tradition (not to mention his left-wing political sympathies) may not be doubted.

The trump role of situational analysis as a theoretical Trojan horse, as well as its especial significance and promise for current anthropology, pivots just here, pointing to Gluckman's deep, underlying attraction to the question of conflict and to the logic of dialectic. By "situation"-though there is no reason to think that he fully intended to restrict the rubric so-Gluckman primarily had in mind situations of conflict. And because he was given to understand conflict in terms of dialectic, this paralogical outlook informed (even if not by explicit design) situational analysis. Accordingly, the extended-case method worked not only to expose structural functionalism's principal inadequacy, but also to intimate the possibility of a paradigm in place of structural functionalism: the extended case bore the seeds of another way of looking at the social altogether, in which the social was pre-eminently a matter of practice.

In devising the extended-case study as a method for empirically ascertaining the actual mechanisms of social process, Gluckman was in effect engaging the Hegelo-Marxian dialectical conundrum of theory and practice. He was shifting the ethnographic focus from the normative to actual practice. Instead of trying to understand social life as a function of its ideal principles and formal rules, and so its theoretical self-presentation, Gluckman moved to understand social life in terms of its lived, concrete reality. Broadly speaking, this move is logically identical to Bourdieu's (as Bourdieu himself sensed ${ }^{2}$ ), when the late French anthropologist turned away from structuralism, in which actual conduct is grasped as a realization of an intellectual formation, to a theory of practice, in which people are seen to act according to the particulars of the situation in 
which they find themselves. These particulars are essentially exigent and contingent matters (historical, experiential, instrumental, socio-cultural, natural, and so forth). Normative principles bear on these matters but do so by virtue of not only their meaning in the abstract but also the demands of the situation. In other words, in practice these principles are deconstructed and reconstructed according to the momentary and the ephemeral, that is, the pre-eminently improvisatory flow of circumstance-in short, process as such.

In order to denote the unification of theory and practice, the Hegelo-Marxian tradition used the rubric praxis. But the exact nature of this unification was not uniformly agreed upon, since different interpretations within the tradition varied significantly as to the relative priority given to the two extremes in relation to each other. In this connection, Gluckman's take remains of considerable interest, even though as an anthropologist of his times he was in no position to see clairvoyantly its potential. As a Durkheimian, he remained interested in identifying the social structural principles from which social action was thought to issue. However, because he was also disposed to see these principles as contradictories, he injected into structural-functionalist orthodoxy a dynamic that implicitly admitted to the possibility of change as such.

It is true that in his well-known distinction between rebellion and revolution, Gluckman laid explanatory emphasis on his (ingenious) functionalist thesis on how rebellion served to reinforce the existing social structure, thereby avoiding fundamental transformation (see, e.g., 1963: intro. and chap. 3; see also 1959). Nonetheless, with his explicit attention to the possibility of revolutionary change, Gluckman implicated the more fundamental sense of process, the sense in which this notion, even when the actual dynamic seems archly conservative, ultimately denotes becoming. Yet, given that in his functionalist argument about rebellion he understood action especially by reference to principle, the picture of praxis he projected there was, as Marx might have said, still too theoretical. Nevertheless, even this theory of rebellion was dialectical and acknowledged the clash of fundamental structural principles. What Gluckman failed to do, though, was to ask why basic structural principles, whatever their particular content, always find themselves at variance with one another. Had he done so, he might have given more radically a certain primacy to process over structure in the dialectic, and therewith abandoned structural functionalism altogether.

Though all praxis entails the shaping of practice by human consciousness, in the end, the latter can exist only on condition of practice. Put another way, though theory will have its day, practice always exceeds and surprises even the best-laid plans and most practicable ideals. Practice generates its own emergent properties, altering itself. However, it is not the case that practice is simply disruptive of or opposed to theory. This is a dualistic preconception (one perhaps going back to Aristotle, who held that theoretical and practical knowledge are mutually exclusive) that, given structural functionalism's normativist bias, plagued those anthropologists of Gluckman's day who endeavored to treat the question of practice. Instead, it is necessary to acknowledge that practice is intrinsically more than-indeed (in, ironically, a Dumontian sense) encompassing of-theory. With this acknowledgement, it becomes possible to make empirically unassailable 
sense of the idea of the unification of theory and practice, by construing it in terms of an open rather than closed dialectic, a unity that denotes allness, not oneness.

This picture of practice as enjoying the final word in regard to theory is implicated by situational analysis, and this is why the latter already amounts to a theory of practice. Considered as a theory of practice, situational analysis is anthropologically distinctive. To see this, it is helpful to return to our example of Firth and Nadel. By introducing the factor of individual choice into structural functionalism, these scholars too were intimating a theory of practice. Doubtless, they were no more acutely aware of this than was Gluckman with respect to his development of situational analysis. But the difference between the resulting theories of practice highlights a striking feature of Gluckman's. Firth's and Nadel's respective turns in the direction of practice depended on the received Western dualism of the individual and society and therefore were wholly theoretical. However, Gluckman's offering was critically more than a matter of theory-it was also a way of empirically determining the actual mechanisms of practice in any particular case. This is why, despite its gravid theoretical content, it was explicitly referred to as a method. In point of fact, situational analysis is at once a practice for empirically investigating practice and an implicit theory of practice, and therefore it promises an ethnographic unification of theory and practice. Even Bourdieu, to whom current anthropology owes its only theoretically elaborated logic of practice, and who so richly produced an 'outline' of a theory of practice, did not create an ethnographic praxis of a theory of practice. ${ }^{3}$ Situational analysis became a way of theorizing practice as it was practiced, and so the embrace of practice and its theorizing inched toward praxis.

Our point is not of course that the extended-case method constituted a fleshedout theory. Rather, our point is that by virtue of its make-up as a developed ethnographic procedure for investigating practice through theoretical situationalism, the extended-case method holds noteworthy, untapped potential for the anthropological turn to practice. In other words, the very practice of situational analysis produces, procedurally, a theory of practice, one that, given its situationalism, comprehends praxis (including ethnographic praxis) as an ongoing, open-ended dialectic, rather than a completed synthesis. Bear in mind that the very idea of situation, considered existentially, presumes not only a predicament but also an agential capacity on the part of the situated (with their different subjectivities) to negotiate the predicament by praxis. That is to say, the 'obstructions' constituting the predicament suppose an agent capacitated to cope with them by practical conduct mediated through choice or meaningful purpose-a free agent, whose freedom is always dynamically relative to his or her situatedness.

\section{The Manchester School-Deceptively Disappeared?}

What happened to situational analysis and the extended-case method? Where did they disappear to? Were we to ask graduate students and younger faculty at major American departments of anthropology whether they knew anything 
substantive about this approach, our educated guess is that nearly all would reply that they did not. In anthropologies smitten with vocabularies of practice, more effort is expended on theorizing practice as an end in itself than on the practice of practice in doing ethnography, theorizing as the ethnography progresses. Since the heyday of the Manchester School, both the theorizing of theory and the theorizing of practice have taken over more and more space in anthropology at the expense of the kinds of detailed ethnographies that enabled the fruitful formulations of situational analyses and extended cases. In discussions of practice, Mancunian situational analysis is simply absent, an absence correlative with the degree to which it has become all too easy to invoke the idea of practice rhetorically, with no substantive employment to speak of.

In 1966, Max Gluckman (1968) delivered a plenary address to the American Anthropological Association, as did Fredrik Barth (1967). Barth's address, in which he spoke of his variety of economistic methodological individualism in relation to the study of social change, was greeted with enthusiasm. Gluckman's flopped, and he returned to Manchester, disheartened. His lecture introduced the concept of 'structural duration'-the period that enables an institution to go through many of its regular alterations or changes that make it as it is, that can only be witnessed through time, and that constitute the cultural and social fullness of that institution (see Handelman, this volume). In earlier Manchester thinking, situational analysis had expanded temporally into the extended case. In this lecture, Gluckman implicitly argued that macro dynamics could become evident only if they were followed through time. In effect, he was asserting that because the extended case depended on the study of practice through time, the method of extended-case studies led to a macro anthropology grounded in practice.

Coming out of Bourdieu, practice theory became big in the United States. We mention briefly two renowned American anthropologists who have adopted practice theory. Marshall Sahlins, now one of the leading American rhetoricians of practice theory, developed the idea of the structure of the conjuncturethe extension of the concomitants of a historical event through time and their temporal structuring through the practice of cultural premises and knowledge of the parties to the event (see Sahlins 1985). Sahlins's ideas resonate with those of Gluckman. Yet nowhere does Sahlins acknowledge the existence of the Manchester School. This absence continues to come through strongly in one of Sahlins's most recent works, subtitled "How Microhistories Become Macrohistories and Vice Versa” (2005).

Another prominent case in point is that of Sherry Ortner. Ortner (2005) touts the theorizing of the actor, and through this the discovery of the subject, as if both had been scarce in anthropology. Her major route of theorizing the actor (as an agential and feeling subject) takes us through practice theory via Bourdieu, Giddens, Sahlins, and her own work, as well as through Clifford Geertz's understanding of the subject as existentially complex, "a being who feels and thinks and reflects, who makes and seeks meaning” (Ortner 2005: 33). Do the scholars she mentions both theorize practice and practice practice? In the main, they certainly do the former. The Manchester School, whose adherents (Victor Turner 
and Clyde Mitchell, among others) practiced practice in many of their analyses, is totally absent from her discussion. She holds up Geertz's interpretation of the Balinese cockfight and Richard Sennett's interviews with American workers under disorienting conditions of late-capitalist workplaces as prime examples of the practice of subjectivities. In both examples, though, practice is reduced to narrative, indeed, to representation. It is in relation to the cockfight that Geertz coined his celebratory phrase-a story that Balinese tell themselves about themselves - thereby reducing ritual practice to the said of a story, ${ }^{4}$ while for Sennett it is crucial that in late-capitalist regimens people regain the capacity "to narrate their lives in a coherent and meaningful way" (Ortner 2005: 44). But the saying always exceeds the said, however coherent, meaningful, and efficacious the latter, and practice is primarily in the saying. ${ }^{5}$

Where did situational analysis and the extended-case study disappear to? We are not speaking here, after all, of an obscure theoretical innovation tucked away in a plodding third-grade university. Certainly, American anthropology disavowed Manchester anthropology, even as US anthropologists cried out their commitment to anthropologies that valued life as it is lived and therefore practiced. In this regard, the huge impact of Victor Turner on American anthropology bears scrutiny. Turner was, after all, a stellar representative of the Manchester School, and his brilliant work on ritual reflects nothing if not the turn of his teacher, Gluckman, to processualism. Yet Turner's social anthropology was assimilated to American cultural anthropology without regard to the fact that he realized his symbolic analyses ethnographically through the use of social dramas, a distinct variant of situational analysis and the extended-case method (see Kapferer, this volume).

American anthropology (in its multiplicities) is crucial here, for it is the dominant power in the anthropological world, by dint of sheer numbers and departments; by the weightiness of the wealth of its universities, foundations, other granting agencies, and fellowships; by its control of major journals and presses whose editorial perspectives are first and foremost American; and by the fluidity of its capital in buying foreign scholars of note. This dominance, perhaps overwhelming, is bound to breed the arrogance of power applied to intellect, and engenders the belief that any approach worth something, and its practitioners and ideas, will already be in or will come to the United States. The general response of world anthropologies to this academic colonizing of the globe is to align themselves as provinces or satellites. American anthropologists are seldom sufficiently subjective and reflexive enough to recognize the consequences and vicissitudes of US domination of global anthropology.

Has the Manchester anthropology we discuss survived? The answer is yes, here and there, in different forms and variants, as the contributions to this volume attest. The last substantive overview of the approach was that of the late Kingsley Garbett in his Malinowski Memorial Lecture of 1970 (Garbett 1970). ${ }^{6}$ Bruce Kapferer brought the approach to Adelaide University, where it was influential for some time. Myron Aronoff (1977), Emanuel Marx (1976), Shlomo Deshen (1970), and Moshe Shokeid (1971) took the approach to 
Israel, where it played a role in the founding of anthropology in Israeli universities. Even in the United States, the approach was, by design, at least introduced by Terry Evens in a collection he co-edited with James Peacock (1990). ${ }^{7}$ Resonances of the approach appear in northern Europe, particularly Scandinavia (witness the contributions to this volume in the section on extended-case studies). Situational analysis and the extended case strongly influenced how anthropologists in Britain came to do field research in British locations (well before such studies became legitimate in the United States, apart from the study of 'minorities'). Ronnie Frankenberg's Village on the Border (1957), done with Gluckman's strong encouragement, marked the beginning of a seminal shift into the anthropological study of rural Britain (see Cohen 2005). So, too, Gluckman encouraged the use of the approach in the study of British industry, for example, in the innovative studies of Cunnison (1966) and Lupton (1963), even as other British anthropologists, especially those at Oxford and Cambridge, insisted that such studies simply were not anthropology. ${ }^{8}$ Is the disappearance of the Manchester School deceptive? The answer is open.

The implications and advantages of situational analysis and the extendedcase method are manifold, extending to matters of ethnographic observation and analysis, to situational flow between the local and the global, to the ontological nature of social life, to reflexive and activist anthropology, and more. Some of these are discussed in various of the essays collected here, and all remain to be explored further in connection with the continuing, substantial promise of the Manchester case-study method and its practice. The last collection to feature the Manchester School case-study method, edited by Bill Epstein (1967), appeared over 35 years ago, and we have gathered the present collection to further convey the promise of which we speak. The essays, though they overlap some in their foci, are organized in three topical sections-theory, history, and case analysis-each of which is prefaced by a brief introduction. We thought it only fitting to leave the last word, the coda, to Bruce Kapferer.

We are grateful to Caroline Baggaley of Sociological Review for her efforts in securing permission for us to reprint Max Gluckman's (1961) and Clyde Mitchell's (1983) articles; ${ }^{9}$ Clyde Mitchell's widow, Jean Mitchell, for granting us permission to use her late husband's article; Vivian Berghahn of Berghahn Journals for her editorial encouragement and efficient assistance; and Shawn Kendrick, whose excellence as copyeditor is, in our experience, without parallel. We would like to acknowledge the sorrowful passing of Kingsley Garbett, who, in his capacity as managing editor of Social Analysis, gently nudged us along in the editorial process. We wish also to acknowledge the sad loss of Marian Kempny, Björn Lindgren, and Karin Norman's husband, Johan, all three well before their time. 


\section{Notes}

1. Naturally, we were aware of Gluckman's propensity, which he makes plain in his essay, "Ethnographic Data in British Social Anthropology" (1961), to see case studies as crucial for analyzing instances of social conflict. But it was Kapferer's insightful description (his essay, this volume) of the fundamental nature of the extended-case study method that moved us here to our own account of the specific contribution of Gluckman's abiding interest in social conflict to the development of situational analysis.

2. In Outline of a Theory of Practice, Bourdieu comments on situational analysis as follows (1977: 26): “[A]nthropologists who appeal to 'context' or 'situation' in order ... to 'correct' what strikes them as unreal and abstract in the structuralist model are in fact still trapped in the logic of the theoretical model which they are rightly trying to supersede. The method known as 'situational analysis' [and here Bourdieu cites Gluckman 1961], which consists of 'observing people in a variety of social situations' in order to determine 'the way in which individuals are able to exercise choices within the limits of a specified social structure', remains locked within the framework of the rule and the exception, which Leach (often invoked by the exponents of 'situational analysis') spells out clearly: 'I postulate that structural systems in which all avenues of social action are narrowly institutionalized are impossible. In all viable systems, there must be an area where the individual is free to make choices so as to manipulate the system to his advantage.' In accepting as obligatory alternatives the model and the situation, the structure and the individual variations, one condemns oneself simply to take the diametrically opposite course to the structuralist abstraction which subsumes variations-regarded as simple variants-into the structure ... [This] leads one to regress to the pre-structuralist stage of the individual and his choices, and to miss the very principle of the structuralist error." What is off target about Bourdieu's (decidedly astute) observation that despite their efforts these anthropologists remained "trapped" in the theory they found wanting is that he assimilates Gluckman's "situational analysis” to Leach's (and thus Firth's and Nadel's) Malinowskian individualistic approaches to the problem. But what we wish to bring out by this quotation from Bourdieu's classic text is that in bothering to distinguish his position from Gluckman's, Bourdieu plainly reveals that he sees well enough the kinship between his own theoretical turn toward practice and Gluckman's. In point of fact, he goes on to note (ibid.: 202n37) that the analyses of Jaap van Velsen, a student of both Gluckman and Clyde Mitchell, "are essentially consistent with my own analysis of the strategic uses made of kin relations" (adding parenthetically, "which I wrote before [van Velsen's] The Politics of Kinship came to my notice").

3. In an appreciative but radical critique, Evens (1999) argues that at bottom Bourdieu's attempt to transcend the dualism of subject and object falls prey to reductionism. If Gluckman's attempt at praxis was too theoretical, then Bourdieu's is too practical. Bourdieu's theory of practice is keyed to what he speaks of as "generalized materialism," by which he means that beyond sheerly material advantage there is augmentation of social being-in effect, symbolic advantage. But as Evens puts it (ibid.: 27n23), because "Bourdieu's concept of the symbolic remains epiphenomenal," it also "remains ontologically ill-equipped to do justice to the surpassing reality of the meaningful side of social existence." In other words, in respect of human practice, which constitutes an essential tension, "materialism, even when it is generalized, is not enough" (ibid.: 30).

4. Handelman (1994: 345) maintains that "Geertz has authored or advertised many memorable phrases: 'models of ... models for,' 'thick description,' 'from the natives' point of view,' 'blurred genres,' and others. These are catchy—-something like scholarly jingles, erudite slogans, scholastic pop tunes ... as I read these phrasings (hum them? chant them? recite them?), their project is not that of concept formation nor of theory-building ... [but rather] refractions of an attitude, a point of view, a subtle sensibility." The reader is invited to pair the Balinese cockfight with Clyde Mitchell's situational analysis of the Kalela dance (1956) in which, rather than enclosing culture in text, Mitchell 
tackled social dynamics as emergent, open-ended formations in mining towns on the Zambian Copperbelt.

5. Regarding her study of her high-school class of 1958, Ortner (2003: 297-298) writes: "The general theoretical framework behind this structure of inquiry and exposition is so-called practice theory, which I mostly leave implicit in the course of the book." The first part of the book situates the study socially and historically in the 1950s. The second part asks what the graduates of the class of 1958 did with themselves and their lives after graduation. The second part is based primarily on interviews. Just how this constitutes "practice" is left up to the reader.

6. Richard Werbner (1984) later did an overview of the approach, but specifically with reference to south-central Africa.

7. The collection comprises a half-dozen extended-case studies on the topic of transcendence and social movements. The studies, based on intensive fieldwork, and all but one by students of Evens and Peacock, were executed, as dictated by the project's blueprint, in accordance with "Max Gluckman's case study method" and are "developed primarily as dynamic, descriptive aids to the discernment of the particular social horizons or limits over and against which the cases unfold, and lend themselves to interpretation in terms of existential tensions" (Evens and Peacock 1990: intro.). The collection appeared as a book supplement of a sociological research annual, of which the series editor was Craig Calhoun (who-a not irrelevant consideration in the present connection-did an MA in social anthropology at Manchester and then a DPhil in sociology at Oxford University, under the supervision of Clyde Mitchell). Regretfully, the vehicle of publication proved obscure, at least in respect of anthropologists who might have taken notice, and the book is still not easy to find.

8. Lupton and Cunnison were among the founders of the Manchester Business School, perhaps the best in Britain (Bruce Kapferer, personal communication).

9. Gluckman's and Mitchell's articles are reprinted in the online edition of the journal, as well as in the book edition of this special issue, published in 2006 by Berghahn Books.

\section{References}

Aronoff, Myron J. 1977. Power and Ritual in the Israel Labor Party. Assen: Van Gorcum.

Barth, Fredrik. 1967. "On the Study of Social Change." American Anthropologist 69: 661-669.

Bourdieu, Pierre. 1977. Outline of a Theory of Practice. Cambridge: Cambridge University Press.

Cohen, Anthony P. 2005. "Village on the Border, Anthropology at the Crossroads: The Significance of a Classic British Ethnography." Sociological Review 53: 603-620.

Cunnison, Sheila. 1966. Wages and Work Allocation. London: Tavistock.

Deshen, Shlomo. 1970. Immigrant Voters in Israel. Manchester: Manchester University Press.

Epstein, A. L., ed. 1967. The Craft of Social Anthropology. London: Social Science Paperbacks in association with Tavistock Publications.

Evens, T. M. S. 1999. "Bourdieu and the Logic of Practice: Is All Giving Indian-Giving or Is ‘Generalized Materialism’ Not Enough?” Sociological Theory 17: 3-31.

Evens, T. M. S., and James Peacock, eds. 1990. Transcendence in Society: Case Studies. Supplement 1 of Comparative Social Research. Series editor: Craig Calhoun. Greenwich, CT: JAI Press.

Firth, Raymond. 1961. Elements of Social Organization. London: Watts \& Co.

Frankenberg, Ronald. 1957. Village on the Border. London: Cohen \& West.

Garbett, Kingsley. 1970. "The Analysis of Social Situations.” Man 5 (n.s.): 214-227.

Gluckman, Max. 1959. Custom and Conflict in Africa. Glencoe, IL: Free Press. 1961. "Ethnographic Data in British Social Anthropology." Sociological Review 9, no. 1: 5-17. 
1963. Order and Rebellion in Tribal Africa. London: Cohen \& West.

1965. Politics, Law and Ritual in Tribal Society. Oxford: Basil Blackwell.

1968. "The Utility of the Equilibrium Model in the Study of Social Change." American Anthropologist 70: 219-237.

Handelman, Don. 1994. "Critiques of Anthropology: Literary Turns, Slippery Bends." Poetics Today 15: 341-381.

Lupton, Tom. 1963. On the Shop Floor: Two Studies of Work Organization and Output. London: Pergamon.

Marx, Emanuel. 1976. The Social Context of Violent Behavior. London: Routledge \& Kegan Paul. Mitchell, J. Clyde. 1956. The Kalela Dance. Manchester: Manchester University Press. 1983. "Case and Situation Analysis." Sociological Review 31: 187-211.

Nadel, S. F. 1957. The Theory of Social Structure. Glencoe, IL: Free Press.

Ortner, Sherry B. 2003. New Jersey Dreaming: Capital, Culture and the Class of '58. Durham, NC: Duke University Press. . 2005. "Subjectivity and Cultural Critique." Anthropological Theory 5: 31-52.

Sahlins, Marshall. 1985. Islands of History. Chicago: University of Chicago Press. . 2005. "Structural Work: How Microhistories Become Macrohistories and Vice Versa." Anthropological Theory 5: 5-30.

Shokeid, Moshe. 1971. The Dual Heritage. Manchester: Manchester University Press.

Werbner, Richard. 1984. "The Manchester School in South-Central Africa." Annual Review of Anthropology 13: 157-185. 